African Journal of Agricultural Research Vol.7(48), pp. 6408-6412, 20 December , 2012

Available online at http://www.academicjournals.org/AJAR

DOI: 10.5897/AJAR12.1515

ISSN 1991-637X @2012 Academic Journals

Full Length Research Paper

\title{
Effect of thiamethoxam and imidacloprid treatment on germination and seedling vigor of dry-heated seed of oil palm (Elaeis guineensis Jacq.)
}

\author{
Wanchai Chanprasert $^{1 \star}$, Theingi Myint ${ }^{2}$, Surakitti Srikul ${ }^{3}$ and Onrat Wongsri ${ }^{3}$ \\ ${ }^{1}$ Department of Agronomy, Faculty of Agriculture, Kasetsart University, Bangkok, 10900 Thailand. \\ ${ }^{2}$ Applied Research Center for Perennial Crops, Mawlamyine, Myanmar. \\ ${ }^{3}$ Surat Thani Oil Palm Research Center, Surat Thani, 84000 Thailand.
}

Accepted 23 November, 2012

\begin{abstract}
Rapid and uniform seedling growth is a pre-requisite for better establishment of oil palm plantations. Chemical pretreatments can be used to increase the rate and uniformity of seed germination. Thiamethoxam and imidacloprid are insecticides classified in the broad-spectrum systemic neonicotinoid group and their use in seed treatment has been claimed to increase seed germination and vigor in some crops. Thiamethoxam at the rate of $0,0.1,0.3,0.6$ and $0.9 \mathrm{~g}$ ai. $\mathrm{L}^{-1}$ of water and imidacloprid at the rate of $0,0.2,0.5,0.9$ and $1.4 \mathrm{~g}$ ai. $\mathrm{L}^{-1}$ of water were evaluated using dry-heated seed (seed with $18 \%$ moisture content heated at $40^{\circ} \mathrm{C}$ for 60 days) to observe the differences in germination response and seedling vigor. The results revealed that imidacloprid at the rate of $0.5 \mathrm{~g}$ ai. $\mathrm{L}^{-1}$ of water significantly increased shoot length while thiamethoxam did not. Both neonicotinoids did not affect the germinated seed percentage, the time taken to reach $50 \%$ germination $\left(T_{50}\right)$ and root length. It can be concluded that imidacloprid could increase seedling vigor by stimulating the shoot growth of dryheated oil palm seed. No phytotoxicity of thiamethoxam and imidacloprid following dry-heated seed germination was observed.
\end{abstract}

Key words: Thiamethoxam, imidacloprid, germination, seedling vigor, tenera oil palm seed.

\section{INTRODUCTION}

Given the current situation, oil palm makes up a prominent part of the volume of international trade, due to a ceaselessly growing demand for palm oil in the world (Martine et al., 2009). In fact, palm oil production will continue to be a world leader for many years because of its variety of food and non-food uses. World production of palm oil has also seen substantial leaps in production through an expansion of the planted area that has been achieved mainly by the opening up of new land (Donough et al., 2009). Cultivation in the new and old areas still

${ }^{*}$ Corresponding author. E-mail: agrwcc@ku.ac.th. uses germinated hybrid seeds as the plant propagation material, although tissue culture technology has been established in breeding programs (Dikin et al., 2003; Martine et al., 2009). Under natural conditions, oil palm seed germination is very slow with a low percentage that represents a major constraint for the establishment of the plantations (Rees, 1963; Martine et al., 2009).

Physical dormancy contributes to the long germination process in oil palm seed (Martine et al., 2009), with commercial tenera oil palm seeds requiring a pretreatment of heating at $40^{\circ} \mathrm{C}$ for 60 days. Fondom et al. (2010) reinvestigated the effect of heat-treatment duration on germination and subsequent seedling growth of 10 oil palm progenies and confirmed that a heat 
treatment at $39 \pm 1^{\circ} \mathrm{C}$ for 60 days was effective for breaking the dormancy of the oil palm seeds and encouraging successful seedling growth. Even though dry heat was developed in order to improve and speed up seed germination for a sustainable supply of germinated seeds to the planters, it appears constraints are associated with the length of time, the expense and the requirement of special installations. Many researchers have been trying various approaches to achieve a higher germination in a shorter time (Wonkyi-Appiah and Amuh, 1979; Murugesan et al., 2005; Myint et al., 2010; Chanprasert et al., 2012). Chemical pretreatment is an aspect that has been introduced into oil palm seed research (Wan and Hor, 1983; Herrera et al., 1988). Thiamethoxam and imidacloprid are insecticides classified in the broad-spectrum systemic neonicotinoid group (Moser and Obrycki, 2009) and their application in seed treatment has been claimed to increase seed germination and vigor in some crops (Horii et al., 2007; Stevens et al., 2008). Thiamethoxam accelerated the germination of soybean seed when used at the recommended level (Cataneo et al., 2010). According to Horii et al. (2007), thiamethoxam had a slightly positive effect on the seed vigor of pea, soybean and corn during germination. Imidacloprid has also been studied as a seed treatment on some crops such as wheat (Pike et al., 1993; Wilde et al., 2001), and barley (Pike et al., 1993). However, the use of thiamethoxam and imidacloprid as seed treatement in oil palm has not yet been reported. The objective of this study was to determine the effects of thiamethoxam and imidacloprid on the germination and vigor of commercial tenera oil palm seed following dormancy which was overcome by a dry-heat treatment.

\section{MATERIALS AND METHODS}

\section{Seed material}

The seeds derived from the oil palm cross no. 37 (Surat Thani 2) were obtained from the progenies of Deli dura (C2120:184D $\times$ HC133:1288D) $\times$ LaMe pisifera $(\mathrm{IRH}$ 618: 158T $\times$ HC129: 1056P) that were the products of a genetic selection program. The seeds utilized in this experiment were collected during 2009 from the palms located at the Surat Thani Oil Palm Research Center $\left(09^{\circ} 07^{\prime} \mathrm{N}, 99^{\circ} 21^{\prime} \mathrm{E}\right)$, southern Thailand belonging to the Department of Agriculture, Ministry of Agriculture and Cooperatives.

Bunches of tenera cross no. 37 (Surat Thani 2) were harvested and the seeds were mechanically depericarped from the fruits, then normal practices for controlling fungal infection were conducted (that is, the seeds were washed with detergent and submerged in a mixture of surfactant and sodium hypochlorite for 20 min followed by dipping in the mixture of benomyl and thiram and left under shade for $24 \mathrm{~h}$ ).

When the moisture content of the seed was about $18 \%$, the airdried seeds of each treatment were put in individual plastic bottle previously treated with alcohol and then heated at $40^{\circ} \mathrm{C}$ for 60 days.
After heating, the seed moisture content was determined. The dry heated seeds were divided into five groups, each treated with a different neonicotinoid concentration including the control.

\section{Control seeds}

According to the results of the seed moisture content analysis, the control seeds were soaked in water for 9 days to raise the moisture content to about $22 \%$ (dry weight basis). The soaked seeds were rinsed with water, washed with detergent then treated with a fungicide mixture, dried under shade for $2 \mathrm{~h}$ and then germinated in polyethylene bags measuring $37 \times 26 \mathrm{~cm}$ at ambient temperature (mean temperature $28 \pm 2^{\circ} \mathrm{C}$ ) under dark conditions.

\section{Neonicotinoid chemical-treated seeds}

Instead of 9 days soaking in water, the dry-heated seeds that were to be applied with neonicotinoids were soaked in water for 8 days then soaked in two different chemical amounts of either thiamethoxam (Cruiser $\left.{ }^{\circledR} 35 \mathrm{FS}\right)\left(0.1,0.3,0.6\right.$ and $0.9 \mathrm{~g}$ ai. $\mathrm{L}^{-1}$ of water or $1.0,2.5,5.0$ and $7.5 \mathrm{ml} \mathrm{kg}^{-1}$ of seed in $3 \mathrm{~L}$ of water) or imidacolprid (Gaucho ${ }^{\circledR} 70 \mathrm{WS}$ - powder) $(0.2,0.5,0.9$ and $1.4 \mathrm{~g}$ ai. $\mathrm{L}^{-1}$ of water or $1.0,2.0,4.0$ and $6.0 \mathrm{~g} \mathrm{~kg}^{-1}$ of seed in $3 \mathrm{~L}$ of water) for $24 \mathrm{~h}$ to raise the moisture content to about $22 \%$. The treated seeds were rinsed with water, washed with detergent then treated with a fungicide mixture, dried under shade for $2 \mathrm{~h}$ and then germinated in the polyethylene bags measuring $37 \times 26 \mathrm{~cm}$ at ambient temperature (mean temperature $28 \pm 2^{\circ} \mathrm{C}$ ) under dark conditions.

\section{Experimental design and statistical analysis}

The moisture content of seeds was determined each time after soaking in water. Five seeds of each treatment were weighed in order to determine their fresh weight (FW) and then dried in an oven at $105^{\circ} \mathrm{C}$ for $48 \mathrm{~h}$ to obtain a constant dry weight (DW). The moisture content was calculated on a seed dry weight basis (Panyangnoi et al., 1997). The germination percentage of the seed was evaluated twice each week, during the 40-day test period. The germination percentage was calculated as

$\mathrm{G} \%=$ (number of seed germinated / number of sampled seeds) $\times$ 100.

The time to $50 \%$ germination $\left(T_{50}\right)$ was determined following Coolbear et al. (1984),

$$
T_{50}=t_{i}+\left[\left\{\left((N+1) / 2-n_{i}\right) /\left(n_{j}-n_{i}\right)\right\} \times\left(t_{j}-t_{i}\right)\right]
$$

where $t_{i}$ is the time before reaching $50 \%, n_{i}$ is the number of seeds emerged at time $t_{i}, N$ is the final number of emerged seeds, $t_{j}$ is the time next after $t_{i}$, and $n_{j}$ is the number of seeds emerged at $t_{j}$.

After 40 days, the cumulative percentage of germination was determined. At the end of experiment, shoot and root length were measured in millimeters using a ruler. Treatments were arranged as a factorial combination of treatments in a completely randomized design with four replications. Forty seeds per replication were used for the germination test. Data were analyzed using an analysis of variance to detect differences between mean parameters. If significant differences were found, the least significant difference was used to determine mean differences between treatments. 
Table 1. Effects of thiamethoxam and imidacloprid at five treatment rates $\left(R_{0}\right.$ to $\left.R_{4}\right)$ on germination and time to reach $50 \%$ germination $\left(T_{50}\right)$ of dry-heated tenera oil palm seed of Surat Thani 2.

\begin{tabular}{|c|c|c|c|c|c|c|}
\hline \multirow{2}{*}{ Treatment rate } & \multicolumn{3}{|c|}{ Germination (\%) } & \multicolumn{3}{|c|}{$T_{50}$ (days) } \\
\hline & Thia & Imida & Mean & Thia & Imida & Mean \\
\hline $\mathrm{R}_{0}$ & 83.75 & 80.63 & 82.19 & 17.86 & 17.95 & 17.91 \\
\hline $\mathrm{R}_{1}$ & 78.13 & 81.25 & 79.69 & 19.50 & 18.83 & 19.17 \\
\hline $\mathrm{R}_{2}$ & 85.00 & 80.63 & 82.81 & 17.03 & 17.46 & 17.24 \\
\hline $\mathrm{R}_{3}$ & 81.88 & 81.25 & 81.56 & 17.71 & 19.46 & 18.58 \\
\hline $\mathrm{R}_{4}$ & 74.38 & 89.38 & 81.88 & 18.97 & 17.82 & 18.39 \\
\hline Mean & 80.63 & 82.63 & & 18.21 & 18.30 & \\
\hline \multicolumn{7}{|l|}{$\operatorname{LSD}_{0.05}$ for } \\
\hline Neonicotinoid (N) & & $\mathrm{ns}^{*}$ & & & ns & \\
\hline Rate ( R ) & & ns & & & ns & \\
\hline $\mathrm{N} \times \mathrm{R}$ & & ns & & & ns & \\
\hline CV\% & & 11.0 & & & 12.9 & \\
\hline
\end{tabular}

${ }^{*} \mathrm{~ns}=$ non significance; Thiamethoxam (Thia) $-\mathrm{R}_{0}=0, \mathrm{R}_{1}=0.1, \mathrm{R}_{2}=0.3, \mathrm{R}_{3}=0.6$ and $\mathrm{R}_{4}=0.9 \mathrm{~g}$ ai. $\mathrm{L}^{-1}$ of water; Imidacloprid (Imida) - $R_{0}=0, R_{1}=0.2, R_{2}=0.5, R_{3}=0.9$ and $R_{4}=1.4 \mathrm{~g}$ ai. $L^{-1}$ of water.

\section{RESULTS AND DISCUSSION}

As shown in Table 1, the germination percentages ranged from 74.38 to $85.00 \%$ for the five concentrations of thiamethoxam and from 80.63 to $89.38 \%$ for the five concentrations of imidaclolprid. There was no stimulating effect of thiamethoxam on germination in this study. Prasanna et al. (2004) also reported that thiamethoxamhad no effect on seed germination in cotton, while some other studies found that seed germination was stimulated by thiamethoxam in soybean, pea and corn (Horii et al., 2007; Cataneo et al., 2010). For the effect of imidacloprid, the germination percentage was $80.63,81.25,80.63,81.25$ and $89.38 \%$ when treated at the rate of $0,0.2,0.5,0.9$ and $1.4 \mathrm{~g}$ ai. $\mathrm{L}^{-1}$ of water, respectively. However, imidacloprid did not significantly increase the germination percentage in this study. The speed of germination indicated by $\mathrm{T}_{50}$ was also not affected by both neonicotinoids (Table 1). These two neonicotinoids showed similar effects on $T_{50}$, attaining an average of 18.21 and 18.30 days for thiamethaxam and imidacloprid, respectively.

There was no significant difference in root length as affected by thiamethoxam and imidacloprid, while there was an interaction between two factors (neonicotinoid $x$ rate) on shoot length (Table 2). No obvious effects of thiamethoxam were observed, while a more pronounced effect of imidacloprid was found. Imidacloprid at the rate of $0.5 \mathrm{~g}$ ai. $\mathrm{L}^{-1}$ of water significantly increased shoot length, while the other rates were not significantly different compared to the untreated control. One problem in oil palm seed germination is fungal infection and fungicides must be applied. In this study, a fungicide treatment procedure prior to the neonicotinoid treatment might interact and lower the effect of the neonicotinoids. Buchholz and Nauen (2002) reported that the application of neonicotinoid as a seed treatment can maximize its uptake into plant tissues. Neonicotinoids are known to interact with the nicotinic acetylcholine receptor (nAchR) (Yamamoto et al., 1995; Matsuda et al., 2000). Binding to nAchRs is increased when the chemical is reduced by electrophilic compounds (phenolic antioxidants) to form positively-charged molecules. Such positively-charged neonicotinoids may possibly affect the electron-transport activities in plant cells that consequently improve seed vigor (Ayyappath et al., 2000; Revellin et al., 2001; Delgarde and Rouland-Lefevre, 2002; Foster et al., 2003). Therefore, the positive effects on shoot growth in this study suggest that further experiments by improving the treatment technique should be continued to attain better results of neonicotinoid seed treatment in oil palm seed germination. In this study, no phytotoxicity from the thiamethoxam and imidacloprid treatments in dry-heated oil palm seed was found, in agreement with our previous report (Chanprasert et al., 2012).

\section{Conclusion}

Two neonicotinoids, thiamethoxam at the rate of $0.1,0.3$, 0.6 and $0.9 \mathrm{~g}$ ai. $\mathrm{L}^{-1}$ of water and imidacloprid at the rate of $0.2,0.5,0.9$ and $1.4 \mathrm{~g}$ ai. $\mathrm{L}^{-1}$ of water showed some positive effects on the seedling vigor of dry-heated oil palm seed. Imidacloprid at the rate of $0.5 \mathrm{~g}$ ai. $\mathrm{L}^{-1}$ of water significantly increased the shoot length of oil palm seedlings. No phytotoxic effect was observed in this experiment. Further research is needed to determine the appropriate treatment procedure to maximize seed 
Table 2. Effects of thiamethoxam and imidacloprid at five treatment rates $\left(R_{0}\right.$ to $\left.R_{4}\right)$ on shoot length and root length $(\mathrm{mm})$ at 1 month after emergence of dry-heated tenera oil palm seed of Surat Thani 2.

\begin{tabular}{|c|c|c|c|c|c|c|}
\hline \multirow{2}{*}{ Treatment rate } & \multicolumn{3}{|c|}{ Shoot length (mm) } & \multicolumn{3}{|c|}{ Root length (mm) } \\
\hline & Thia & Imida & Mean & Thia & Imida & Mean \\
\hline $\mathrm{R}_{0}$ & $5.28^{a b_{\star}}$ & $5.38^{\mathrm{bc}}$ & 5.33 & 20.23 & 18.18 & 19.20 \\
\hline $\mathrm{R}_{1}$ & $5.43^{\mathrm{ab}}$ & $4.85^{c}$ & 5.14 & 15.53 & 16.50 & 16.01 \\
\hline $\mathrm{R}_{2}$ & $5.63^{\mathrm{ab}}$ & $6.58^{a}$ & 6.10 & 21.20 & 19.48 & 20.38 \\
\hline $\mathrm{R}_{3}$ & $6.23^{\mathrm{a}}$ & $4.58^{\mathrm{C}}$ & 5.40 & 22.18 & 15.13 & 18.65 \\
\hline $\mathrm{R}_{4}$ & $5.05^{b}$ & $5.90^{\mathrm{ab}}$ & 5.48 & 16.85 & 17.85 & 17.35 \\
\hline Mean & 5.52 & 5.46 & & 19.20 & 17.43 & \\
\hline \multicolumn{7}{|l|}{$\operatorname{LSD}_{0.05}$ for } \\
\hline Neoniotinoid (N) & & ns & & & ns & \\
\hline Rate ( R ) & & ns & & & ns & \\
\hline $\mathrm{N} \times \mathrm{R}$ & & 1.02 & & & ns & \\
\hline CV\% & & 17.9 & & & 6.7 & \\
\hline
\end{tabular}

* Mean values followed by the same letters are not significantly different at the probability level of $p=0.05$. Thiamethoxam (Thia) - $R_{0}=0, R_{1}=0.1, R_{2}=0.3, R_{3}=0.6$ and $R_{4}=0.9 \mathrm{~g}$ ai. $L^{-1}$ of water. Imidacloprid (Imida) $-R_{0}=0, R_{1}=0.2, R_{2}=0.5, R_{3}=0.9$ and $R_{4}=1.4 \mathrm{~g}$ ai. $\mathrm{L}^{-1}$ of water

germination and seedling vigor of oil palm.

\section{ACKNOWLEDGEMENTS}

The authors acknowledge the partial financial support from OPTD (Oil Palm Technology Development for Commercial Bio-diesel Industry in Newly Planted Area Project) of Kasetsart University, the Energy Policy and Planning Office, Ministry of Energy and FAO (OPEC fund for the International Development Project, Ministry of Agriculture and Irrigation, Myanmar). Thanks are also extended to the staff at the Surat Thani Oil Palm Research Centre, southern Thailand for their help throughout the experimental period.

\section{REFERENCES}

Ayyappath R, Polavarapu S, McGuire M (2000). Effectiveness of thiamethoxam-coated spheres against blueberry maggot files (Diptera: Tephritidae). J. Econ. Entomol. 93:1473-1479.

Buchholz A, Nauen R (2002). Translocation and translaminar bioavailability of two neonicotinoid insecticides after foliar application to cabbage and cotton. Pest.Manage. Sci. 58:10-16.

Cataneo AC, Ferreira LC, Carvalho JC, Andréo-Souza Y, Corniani N, Mischan MM, Nunes JC (2010). Improved germination of soybean seed treated with thiamethoxam under drought conditions. Seed Sci. Technol. 38:248-251.

Chanprasert W, Myint T, Srikul S, Wongsri O (2012). Effects of neonicotinoid and method of breaking dormancy on seed germination and seedling vigour of oil palm (Elaeis guineensis Jacq.). J. Oil Palm. Res. 24:1227-1234.

Coolbear P, Francis A, Grierson D (1984). The effect of low temperature pre-sowing treatment in the germination performance and membrane integrity of artificially aged tomato seeds. J. Exp. Bot. 35:1609-1617.

Delgarde S, Rouland-Lefevre C (2002). Evaluation of the effects of thiamethoxam on three species of African termite (Isoptera: Termitidae). Crop Pests J. Econ. Entomol. 95:531-536.

Dikin A, Sijam K, Ahmad ZAM, Seman IA (2003). Biological Control of Seedborne Pathogen of Oil Palm, Schizopyllum commune Fr. with Antagonistic Bacteria. Int. J. Agric. Biol. 5:507-512.

Donough CR, Witt C, Fairhurst TH (2009). Yield intensification in oil palm plantations through best management practice. Better Crops. 93:12-14.

Fondom NY, Etta CE, Mih AM (2010). Breaking seed dormancy: revisiting heat-treatment duration on germination and subsequent seedling growth of oil palm (Eiaeis guineensis Jacq.) progenies. World J. Fungal Plant Biol. 1:51-58.

Foster SP, Denholm I, Thompson R (2003). Variation in response to neonicotinoids insecticides in peach-potato aphids, Myzus persicae (Hemiptera: Aphididae). Pest Manag. Sci. 59:166-173.

Herrera J, Alizaga R, Guevara E (1988). Use of chemical treatments to induce seed germination in oil palm Elaeis guineensis Jacq. ASD Oil Palm Paper 18: 1-16. Available at http://asd-cr.com/ASD-Pub/Bol 18/B18cl ing.htm. (Sourced: August 2007).

Horii A, McCue P, Shetty K (2007). Enhancement of seed vigour following insecticide and phenolic elicitor treatment. Bioresour.Technol. 98:623-632.

Martine BM, Laurent KK, Pierre BJ, Eugene KK, Hilaire KT, Justin KY (2009). Effect of storage and heat treatments on the germination of oil palm (Elaeis guineensis Jacq.) seed. Afr. J. Agric. Res. 4:931-937.

Matsuda K, Shimomura, M, Kondo, Y, Ihara M, Hashigami K, Yoshida N, Raymond V, Mongan, NP, Freeman JC, Komai K, Sattelle DB (2000). Role of loop D of the 7 nicotinic acetylcholine receptor in its interaction with the insecticide imidacloprid and related neonicotinoids. Br. J. Pharmacol. 130:981-986.

Moser SE, Obrycki JJ (2009). Non-target effects of neonicotinoid seed treatments; mortality of coccinellid larvae related to zoophytophagy. Biol. Control. 51:487-492.

Murugesan P, Mathur, RK, Pallai RSN, Babu MK (2005). Effect of accelerated aging on seed germination of oil palm (Elaeis guineensis Jacq.var.dura Becc.). Seed Technol. 27:108-112.

Myint T, Chanprasert W, Srikul, S (2010). Germination of seed of oil palm (Elaeis guineensis Jacq.) as affected by different mechanical scarification methods. Seed Sci. Technol. 38:635-645.

Panyangnoi K, Srikul S, Korawis C (1997). Study on some morphologies of oil palm seeds. Thai. Agric. Res. J. 15:185-193. 
Pike KS, Reed GL, Graf GT, Allison D (1993). Compatibility of imidacloprid with fungicides as a seed-treatment control of Russian wheat aphid (Homoptera: Aphididae) and effect on germination, growth, and yield of wheat and barley. J. Econ. Entomol. 86:586-593.

Prasanna AR, Bheemanna M, Patil BV (2004). Phytotonic and phytotoxic effects of thiamethoxam 70 WS on cotton. Karnataka J. Agric. Sci. 17:334-336.

Rees AR (1963). Germination of palm seeds using a method developed for the oil palm. Principes 7:27-30.

Revellin C, Giraud JJ, Silva N, Wadoux P, Catroux G (2001). Effect of some granular insecticides currently used for the treatment of maize crops (Zea mays) on the survival of inoculated Azospirillum lipoferum. Pest. Manag. Sci. 57:1057-1080.

Stevens MM, Reinke RF, Coombes NE, Helliwell S, Mo J (2008). Influence of imidacloprid seed treatments on rice germination and early seedling growth. Pest Manag. Sci. 64:215-222.
Wan CK, Hor HL (1983). A study on the effects of certain growth substances on germination of oil palm (Elaeis guineensis Jacq.) seed. Pertanika (Malasya) 6:45-48.

Wilde GE, Whitworth RJ, Claasen M, Shufran RA (2001). Seed treatment for control of wheat insects and its effect on yield. J. Agr. Urban Entomol. 18:1-11.

Wonkyi-Appiah JB, Amuh IKA (1979). Preliminary investigation into the use of gamma irradiation to induce germination in the seed of oi palm (Elaeis guineensis jacq.). Ghana J. Agric. Sci. 9:235-236.

Yamamoto I, Yabuta G, Tomizawa M, Saito T, Miyamoto T, Kagabu S (1995). Molecular mechanism for selective toxicity of nicotinoids and neonicotinoids. J. Pesticide Sci. 20:33-40. 